\title{
SISTEM INFORMASI PENJADWALAN MENGAJAR DAN PENGOLAHAN NILAI RAPORT SISWA PADA SMP NEGERI 2 MAJALAYA KARAWANG BERBASIS WEB
}

\author{
${ }^{1}$ Nurly Dalistika, ${ }^{2}$ Yahya Suherman \\ E-mail : ${ }^{1}$ nuriydalistika401@ gmail.com, ${ }^{2}$ yahya.suherman@dosen.rosma.ac.id
}

\begin{abstract}
Abstrak
Pemanfaatan teknologi informatika dalam usaha khususnya bidang pendidikan dapat mengurangi potensi terjadinya kesalahan pengolahan data dibanding pengolahan data secara manual. Penelitian ini bertujuan membangun sistem informasi penjadwalan mengajar dan pengolahan nilai raport siswa pada SMPN 2 Majalaya. Keuntungannya adalah untuk memberikan kemudahan dalam melakukan pengolahan nilai raport dan penjadwalan mengajar. Aplikasi ini diimplementasikan dengan bahasa pemograman PHP, database MySQL sebagai media penyimpanan data. Metode pengujian menggunakan black box testing dengan pendekatan terstruktur. Pendekatan terhadap pengembangan sistem yang dilengkapi dengan alat flowmap, diagram konteks, DFD, kamus data, ERD, hubungan tabel dan metode waterfall yang membuat bentuk awal dari sistem yang akan diciptakan dan terus diuji dan dikembangkan. Penjadwalan mengajar dan pengolahan nilai raport pada SMPN 2 Majalaya masih dilakukan secara manual, sehingga dapat menimbulkan kesalahan data yang disebabkan oleh faktor kesalahan manusia. Aplikasi berbasis web ini dirancang secara online sehingga guru dan wali kelas dapat melihat jadwal mengajar dan menginput nilai siswa. Hasil dari penjadwalan mengajar dan pengolahan nilai raport siswa dapat dilihat dan diproses sebagai laporan berupa informasi yang berguna bagi guru wali kelas dan siswa. Hasil penelitian ini diharapkan dapat menjawab kesulitan yang seringkali dihadapi oleh bagian pengajaran, bagian kurikulum, guru dan wali kelas sehingga bisa jauh lebih efisien dan efektif. Aplikasi ini diharapkan juga dapat menjadi referensi bagi peneliti lain dan kemudian dapat mengembangkannya untuk penelitian selanjutnya.

Kata Kunci : Penjadwalan Mengajar, Pengolahan Nilai Raport, web
\end{abstract}

\begin{abstract}
Utilization of informatics technology in business especially in education field can reduce the potential mistake of data processing compared to manual data processing. This study aims to build information system of teaching scheduling and processing of student report cards at SMPN 2 Majalaya. The advantage is to provide convenience in processing the value of report cards and teaching scheduling. This application is implemented with, PHP programming language, MySQL database as data storage media. Test method using black box testing with structured approach. Approach to the development of systems equipped with flow map tools, context diagrams, DFD, data dictionary, ERD, table relationships and waterfall methods that create the initial form of the system to be created and continuously tested and developed. Scheduling teaching and processing of report cards in SMPN 2 Majalaya are still done manually, so these can cause data errors caused by human error factor. This web-based application is designed online so teachers and homers can see the teaching schedule and input student grades. The results of scheduling teaching and processing of student report cards can be viewed and processed as reports in the form of useful information for homeroom teachers and students. The results of this study are expected to answer the difficulties that are often faced by the teaching, curriculum, teachers and homeroom so that it can be much more efficient and effective. This application is also expected to be a reference for other researchers and then can develop it for further research.
\end{abstract}

Keywords: Scheduling Teaching, Processing of Raport Values, Web

Jurnal Interkom Vol. 13 No. 4 - Januari 2019 


\section{Pendahuluan}

Kemajuan teknologi sangatlah pesat, perkembanganya kian hari kian meningkat dan persaingan dalam bidang industri pun kian ketat, tiap produsen saling berlomba untuk menciptakan teknologi-teknologi canggih yang dapat menunjang pekerjaan manusia. Tak terkecuali dalam bidang teknologi komputer, yang saat ini sudah merupakan kebutuhan yang sangat vital dalam kehidupan sehari-hari. Hal ini dikarenakan manfaat komputer sangatlah besar dalam menunjang pekerjaan. Selain itu komputer juga dapat memberikan informasi yang cepat, tepat dan akurat. Kelebihan lain dari komputer juga dapat mengurangi potensi terjadinya kesalahan pengolahan data dibanding pengolahan data secara manual, tapi tentunya semua ini tergantung dari kualitas sumber daya manusia yang mengoperasikan komputer.

SMP Negeri 2 Majalaya Karawang merupakan suatu lembaga pendidikan milik negara yang memiliki peran untuk mencerdaskan anak bangsa. SMP Negeri 2 Majalaya berdiri pada tahun 2007 sebagai sekolah negeri yang merupakan satu-satunya sekolah di lingkungan Perumahan Citra Kebun Mas dipimpin oleh Kepala Sekolah bernama Bapak Drs. Obar Subarja dan Wakilnya bernama Ibu Dra. Sri Rahayu. Di SMP Negeri 2 Majalaya terdapat 29 ruang kelas untuk para siswa dari kelas VII sampai dengan kelas IX, pada SMPN 2 Majalaya ini memiliki fasilitas untuk para siswa seperti Lab. Komputer, Perpustakaan, Aula Serbaguna dan Musholah, selain fasilitasfasilitas ruangan tersebut para siswa juga bisa memilih ekstrakurikuler seperti Volly ball, Basket ball, Pramuka, Paskibra, PMR dan Rohis. Di SMPN 2 Majalaya ada tiga tingkatan dari kelas VII sampai dengan kelas IX dengan jumlah 1.149 siswa, untuk kelas VII dengan jumlah 359 siswa, kelas VIII dengan jumlah 382 siswa dan kelas IX dengan jumlah 408 siwa,. untuk kelas VII ada 9 ruang kelas dan untuk kelas VII dan kelas IX 10 ruang kelas, satu ruang kelas ada 38 siswa sampai 40 siswa dan ada 59 pegawai dan guru yang mengajar di SMPN 2 Majalaya dengan berbagai mata pelajaran.

Penjadwalan mengajar di SMPN 2 Majalaya saat ini masih secara manual yang dicatat dalam buku kesiswaan, padahal proses manual terkadang berakibat pada kurang lancarnya proses pengadministrasian dan membutuhkan proses yang lama sehingga diperlukan sistem komputerisasi penjadwalan mengajar yang bertujuan mendukung, memperlancar dan mempertinggi kualitas pendidikan. Sampai saat ini penjadwalan pelajaran di SMPN 2 Majalaya masih dilakukan secara manual oleh bagian tata usaha dan bagian kurikulum, yang sebelumnya dilakukan rapat pembagian tugas bersama guru mata pelajaran. Dari penentuan banyaknya kelas, banyaknya guru di sekolah dan banyaknya jam mengajar untuk tiap guru masih dilakukan secara manual. Dengan terbatasnya guru mata pelajaran yang ada, penyusun jadwal dituntut untuk tetap bisa memenuhi kebutuhan sesuai dengan kelas yang tersedia, karena beberapa guru sudah tersertifikasi yang menuntut seorang guru harus memiliki jam mengajar minimal 32 jam pelajaran dalam satu minggu. Staf tata usaha dan bagian kurikulum berkerja sama untuk mengatur jadwal mengajar guru, bagian kurikulum menyusun pembagian tugas guru dan jadwal pelajaran kemudian menyerahkan laporan tersebut ke bagian tata usaha yang akan membuat jadwal tersebut lalu akan diberitahukan kepada siswa dan kemudian akan dilaporkannya kepada kepala sekolah.

Pada pengolahan nilai raport masih dikerjakan secara manual dengan dicatat kedalam buku besar seperti buku daftar nilai, buku ledger dan buku induk register. Prosedur pengolahan nilai raport dimulai dari siswa mengikuti setiap ujian yang dilakukan oleh pihak sekolah seperti ulangan harian, ujian tengah semester dan ujian akhir sekolah. Kemudian guru mengumpulkan hasil belajar siswa ke dalam buku daftar nilai, setelah itu guru akan menyerahkan buku daftar nilai ke walikelas dan kemudian walikelas mencatat nilai kedalam buku ledger dan melaporkan tugasnya kepada kepala sekolah, lalu walikelas bisa mencatat nilai siswa kedalam buku raport. Setelah itu walikelas bisa memberikan buku ledger kepada bagian tata usaha dan akan mencatat nilai ke dalam buku induk register.

Setiap kegiatan yang ada di SMP Negeri 2 Majalaya Karawang, harus dapat dilaksanakan 
dengan baik dan dapat selesai tepat pada waktunya. Misalnya, dalam membuat jadwal mengajar dan mengolah nilai siswa untuk mendapatkan nilai raport setiap semester, kegiatan ini dilakukan bagian pengajaran, guru mata pelajaran dan walikelas. Pembuatan jadwal mengajar dilakukan setelah pembagian kelas selesai karena jadwal akan dibuat berdasarkan jumlah kelas yang tersedia. Bagian kurikulum memberikan dokumen berisi tujuan mengajar guru ke bagian kepegawaian untuk dicetak menjadi surat tugas mengajar dan disetujui kepala sekolah. Surat tugas mengajar yang disetujui, dibagikan kepada guru mata pelajaran dan bagian pengajaran, bagian pengajaran akan membuat jadwal mengajar sesuai dengan surat tugas mengajar. Dalam membuat jadwal mengajar haruslah teliti, bagian pengajaran perlu melakukan pengecekan jumlah jam mengajar yang ditugaskan pada setiap guru mata pelajaran agar guru tersebut tidak mengajar lebih dari jam yang ditugaskan dan memeriksa jadwal supaya guru tidak masuk ke dalam kelas yang ada pada jam pelajaran tertentu yang sudah terisi oleh guru lain. Sedangkan untuk mendapatkan nilai semester dari satu kelas guru mata pelajaran memberikan daftar nilai siswa kepada walikelas dimana daftar nilai tersebut diterima dalam bentuk lembaran daftar nilai. Kemudian walikelas menyalin nilai siswa ke dalam buku raport berdasarkan data nilai yang diterimanya. Selain itu walikelas juga membuat rekap nilai siswa yang akan diberikan ke bagian staf tata usaha dan membuat ledger yang berisi nilai siswa selama satu tahun ajaran.

Sistem informasi penjadwalan dan pengolahan nilai raport yang berbasis web ini diharapkan pihak sekolah dapat membagikan lembaran raport siswa tepat pada waktunya. Selain itu, bidang kurikulum bisa segera mendapatkan data yang dibutuhkan seperti ledger dan rekap nilai siswa. Dalam proses pembuatan jadwal mengajar pun bagian pengajaran tidak perlu sering melakukan pengecekan terhadap jumlah jam mengajar guru maupun jadwal sebab pengecekan tersebut dilakukan oleh sistem. Sistem akan memberi tahu bagian pengajaran jika terjadi kesalahan input dalam proses pembuatan jadwal mengajar.
Berdasarkan uraian tersebut dipilih untuk topik permasalahan yang akan dibahas dengan judul "Sistem Informasi Penjadwalan Mengajar dan Pengolahan Nilai Raport Siswa Pada SMP Negeri 2 Majalaya Karawang Berbasis Web".

\section{Tinjauan Pustaka}

\section{Pengertian Sistem}

Menurut Jeperson Hutahaean (2014:2), "Sistem merupakan suatu jaringan kerja dari prosedur-prosedur yang saling berhubungan, berkumpul bersama-sama untuk melakukan kegiatan atau untuk melakukan sasaran yang tertentu".

\section{Pengertian Informasi}

Menurut Gordon B. Davis dalam Jeperson Hutahaean, (2014:9), "informasi adalah data yang diolah menjadi suatu bentuk yang telah berguna dan lebih berarti bagi penerimanya dan mempunyai nilai nyata atau yang dapat dirasakan dalam keputusan-keputusan yang sekarang atau keputusan-keputusan yang akan datang".

\section{Pengertian Sistem Informasi}

Menurut Jeperson Hutahaean (2014:13), "sistem informasi merupakan suatu sistem didalam suatu organisasi yang mempertemukan kebutuhan pengelolaan transaksi harian, mendukung operasi, bersifat manajerial, dan kegiatan strategi dari suatu organisasi dan menyediakan pihak luar tertentu dengan laporanlaporan yang dibutuhkan".

\section{Pengertian PHP}

Menurut Anton Subagia (2016:3), "PHP merupakan kependekan dari Personal Home Page (situs personal) sebuah pemograman yang berjalan dalam sebuah web server (server side). PHP diciptakan oleh programmer Unis dan Perl bernama Rasmus Lerdoft pada bulan AgustusSeptember 1994".

\section{Pengertian MySQL}

Menurut Anhar (2010:21), "MySQL (My Structure Query Language) adalah sebuah perangkat lunak sistem manajemen basis data 
SQL (DataBase Management System) atau $D B M S$ dari sekian banyak DBMS, seperti Oracle, Ms SQL, Postagre SQL. MySQL merupakan DBMS yang multithread, multi-user, yang bersifat gratis di bawah lisensi GNU General Public Licence (GPL)".

\section{Konsep Kurikulum Tingkat Satuan Pendidikan (KTSP)}

Menurut Abdullah Idi (2016:229), "kurikulum merupakan salah satu komponen yang sangat menentukan dalam suatu sistem pendidikan. Oleh karena itu, kurikulum merupakan alat untuk mencapai tujuan pendidikan dan sekaligus sebagai pedoman dalam pelaksanaan pengajaran pada semua jenis dan tingkat pendidikan".

\section{Kurikulum Tingkat Satuan Pendidikan}

Menurut Abdullah Idi (2016:231), "KTSP dalam peraturan pemerintah No.19 Tahun 2005 tentang Standar Nasional Pendidikan Bab 1 pasal 1 ayat (15) Kurikulum Tingkat Satuan Pendidikan (KTSP) adalah kurikulum operasional yang disusun oleh dan dilaksanakan di masing-masing satuan pendidikan".

\section{Pengertian Penjadwalan}

Wahyu Triyanto (2013:42), dalam jurnal "Sistem Informasi Penjadwalan Mengajar dan Pengolahan Nilai Raport Secara Multiuser Pada SMK Bhinneka Karya Simo Boyolali, penjadwalan didefinisikan sebagai proses mengalokasikan sumber daya yang ada untuk menjalankan sekumpulan tugas-tugas dalam jangka waktu tertentu".

\section{Pengertian Nilai}

Ahlung Arniyanto dan Anggit Dwi Hartanto (2013:39) dalam jurnal "Sistem Informasi Pengolahan Nilai Raport Pada Siswa SMP Negeri 1 Yogyakarta Berbasis Web", nilai adalah rujukan dan keyakinan dalam menentukan pilihan. Selain itu nilai dapat diartikan sebagai patokan normative dalam menentukan pilihan diantaranya cara-cara atau tindakan alternatif".

\section{Pengertian Raport}

Wahyu Triyanto (2013:42), dalam jurnal "Sistem Informasi Penjadwalan Mengajar dan Pengolahan Nilai Raport Secara Multiuser Pada SMK Bhinneka Karya Simo Boyolali”, raport adalah laporan hasil kegiatan belajar siswa selama periode tertentu yang diimplementasikan dalam bentuk nilai sekelompok mata pelajaran dengan disertai penilaian kepribadian, sikap dan tingkah laku periode yang dimasukkan adalah periode atau jenjang belajar yang berupa periode semesteran ( 6 bulan)".

\section{Metode Penelitian}

\section{Metode Pengembangan Sistem}

Metode pengembangan sistem yang digunakan adalah model waterfall, waterfall terdiri atas beberapa tahapan aliran aktifitas yang berjalan satu arah dari awal sampai akhir proyek pengembangan sistem.

Model SDLC air terjun (waterfall) sering juga disebut model sekuensial linier (sequential linear)/ alur hidup klasik (classic life cycle). Menyediakan pendekatan alur hidup perangkat lunak secara sekuensial atau terurut dimulai dari analisis, desain, pengodean, pengujian, dan tahap pendukung (support), seperti pada Gambar 1 yang meliputi beberapa proses diantaranya :

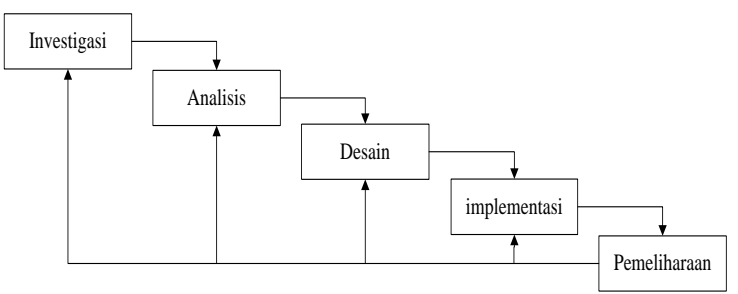

Gambar 1. Skema waterfall

Sumber: Aunur R. Mulyarto (2008)

\section{Investigasi}

Tahap investigasi dilakukan untuk menentukan apakah terjadi suatu masalah atau adakah peluang suatu sistem informasi dikembangkan. Pada tahapan ini studi kelayakan perlu dilakukan untuk menentukan apakah aplikasi yang akan dikembangkan merupakan solusi yang layak. 
2. Analisis Sistem

Metode ini dilakukan untuk mengetahui apa saja kebutuhan sistem informasi penjadwalan dan pengolahan nilai raport dengan pengumpulan data sebagai berikut yaitu :

a. Observasi

Merupakan pengamatan secara langsung terhadap permasalahan yang sedang diteliti pada bagian tata usaha seperti mengetahui alur/prosedur penjadwalan dan pengolahan nilai raport siswa.

b. Wawancara

Merupakan teknik pengumpulan data dengan mengadakan tanya jawab secara langsung ke pihak SMP Negeri 2 Majalaya Karawang.

c. Studi Literatur

Merupakan pengumpulan data dengan cara mengumpulkan literatur, jurnal, buku dan bacaan-bacaan yang ada kaitannya dengan judul peneliti.

d. Desain

Desain perangkat lunak adalah proses multi langkah yang fokus pada desain pembuatan program perangkat lunak termasuk struktur data, arsitektur perangkat lunak, representasi antarmuka, dan prosedur pengodean. Tahap ini mentranslasi kebutuhan perangkat lunak dari tahap analisis kebutuhan ke representasi desain agar dapat diimplementasikan menjadi program pada tahap selanjutnya. Desain perangkat lunak yang di hasilkan pada tahap ini juga perlu didokumentasikan. Desain perangkat lunak pada Sistem Informasi Penjadwalan Mengajar dan Pengolahan Nilai Raport ini menggunakan MySQL sebagai database, Flowchart sebagai model alur sistem, ERD (Entity Relationship Diagram) sebagai rancangan model relasi antar database, dan DFD (Data Flow Diagram).

3. Implementasi

Tahap implementasi merupakan tahapan untuk mendapatkan atau mengembangkan hardware dan software (pengkodean program), melakukan pengujian, pelatihan dan perpindahan ke sistem baru. Pembuatan kode program pada perancangan website sebagai informasi lowongan kerja ini menggunakan aplikasi Adobe Dreamweaver, dengan bahasa pemrograman menggunakan PHP dan HTML. Serta menggunakan CSS untuk mendesain tampilan web.

4. Pemeliharaan

Tahapan pemeliharaan (maintenance) dilakukan ketika sistem informasi sudah dioperasikan. Pada tahapan ini dilakukan monitoring proses, evaluasi dan perubahan (perbaikan) bila diperlukan.

\section{Hasil Penelitian dan Pembahasan}

Semua permasalahan yang ada penulis memberikan solusi dengan perancangan sistem menggunakan aplikasi website. Beberapa alternatif pemecahan masalah tersebut diantaranya adalah :

1. Membuat sistem informasi mengenai datadata nilai siswa dan data mengajar guru sehingga dapat dilakukan dengan mudah dan cepat.

2. Menggunakan aplikasi website sebagai sarana dimana siswa dapat melihat informasi tentang nilai UTS dan nilai UAS.

\section{Usulan Prosedur yang Baru}

\section{a. Prosedur Usulan Penjadwalan}

1) Bagian kurikulum menyerahkan data guru mengajar ke bagian pengajaran dan menerima revisi data guru mengajar dari bagian pengajaran.

2) Bagian pengajaran menerima data guru mengajar dan mengecek kembali apa sudah benar data guru mengajar jika belum bagian pengajaran mengembalikan dokumen data guru mengajar ke bagian kurikulum, jika sudah benar bagian pengajaran akan menginput data guru mengajar dan membuat surat tugas mengajar dua rangkap, rangkap satu akan diserahkan ke kepala sekolah untuk disetujui dan rangkap dua sebagai arsip dan menerima revisi surat tugas mengajar dari kepala sekolah. 
3) Kepala sekolah menerima surattugas mengajar guruuntuk ditandatangani, kemudian kepala sekolah menyerahkan surat tugas mengajar guru ke bagian pengajaran.

4) Bagian pengajaran surat tugas mengajar yang sudah ditandatangani oleh kepala sekolah, kemudian bagian pengajaran menginput jadwal mengajar guru dan mencetak jadwal mengajar lalu memberikan jadwal mengajar dan surat mengajar ke guru mata pelajaran

5) Guru mata pelajaran menerima surat tugas mengajar guru dan jadwal megajar dari bagian pengajaran, kemudian guru mengecek apakah jadwal sudah benar atau belum, jika belum maka guru akan merevisi jadwal mengajar dan memberikan jadwal mengajar yang sudah direvisi ke bagian pengajaran.

6) Bagian pengajaran menerima jadwal mengajar revisi dari guru lalu membuat jadwal baru dan menyerahkanya kembali ke guru mata pelajaran.

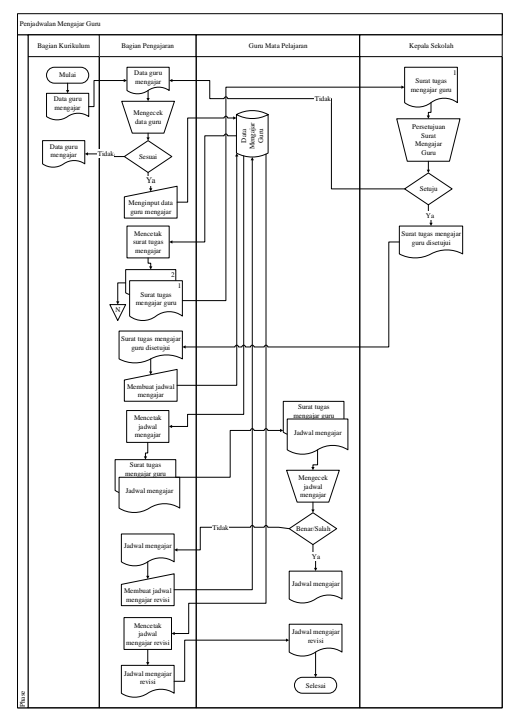

Gambar 2. Flowchart Sistem Usulan

Penjadwalan Mengajar Guru. b. Usulan Prosedur Pengolahan Nilai Raport

1) Guru Mata Pelajaran memberikan rekap nilai seperti nilai tugas, nilai ulangan harian, nilai ulangan tengah semester dan nilai ulangan akhir semester kepada wali kelas.

2) Wali kelas menerima rekapan nilai dari guru mata pelajaran lalu wali kelas menginput nilai ke dalam database kemudian wali kelas merekap nilai siswa dan mencatat nilai siswa ke dalam buku ledger. Kemudian wali kelas menginput nilai raport dan mencetak nilai raport. Raport dan ledger diberikan ke kepala sekolah untuk ditandatangani sedangkan rekap nilai siswa di arsipkan oleh wali kelas dan ledger di berikan ke bagian tata usaha dan raport diberikan ke siswa.

3) Kepala sekolah menerima buku ledger dan buku raport untuk ditandatangani.

4) Tata usaha menerima buku ledger dari wali kelas, kemudian tata usaha mencatat nilai ledger ke dalam buku induk register.

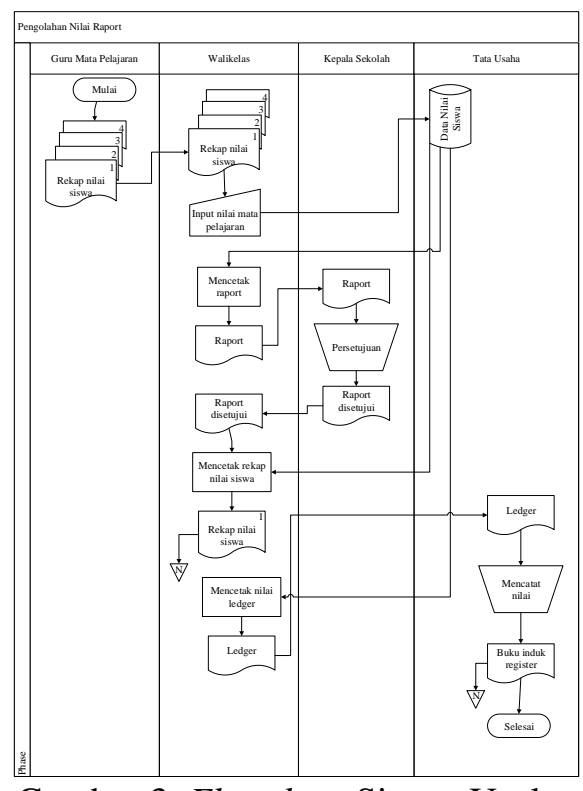

Gambar 3. Flowchart Sistem Usulan

Pengolahan Nilai Raport.

Sumber : Hasil olah peneliti, 2017. 


\section{Implementasi Sistem}

Penulis didalam penelitian pembuatan program aplikasi sistem informasi penjadwalan mengajar dan pengolahan nilai raport siswa berbasis web menggunakan software aplikasi pemrograman PhpMyAdmin pengolah database.

\section{a. Tampilan Layar}

Tampilan layar terdiri dari tampilan layar masukan dan tampilan layar keluaran.

1) Tampilan Layar Masukan

Tampilan layar masukan terdiri dari beberapa form yaitu :

a) Form Login

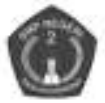

SMP Negeri 2 Majalaya

Sistem Ponjadwalan dan Penilaian

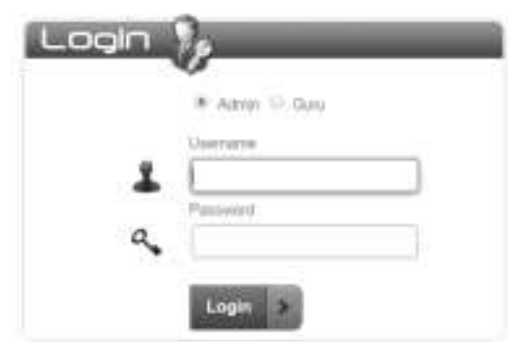

Gambar 4. Tampilan Form Login.

b) Form Menu Utama Admin

Gambar 5. Form Menu Utama (Home).

c) Form Input Nilai Tugas

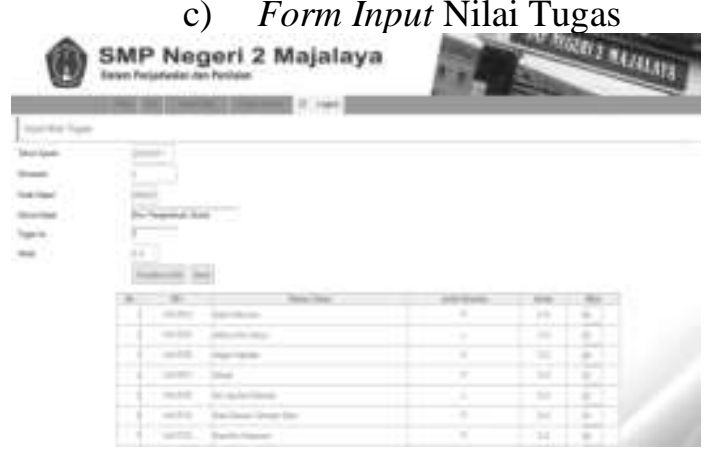

Gambar 6. Tampilan Form Input Nilai Tugas. d) Form Input Nilai UTS

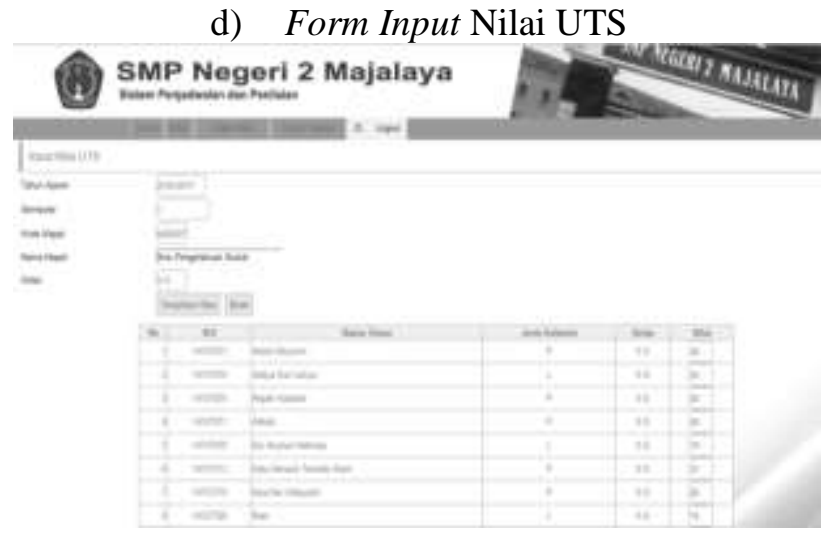

Gambar 7. Tampilan Form Input Nilai UTS.

2) Tampilan Layar Keluaran

Tampilan layar keluaran terdiri dari beberapa form yaitu :

a) Tampilan Output Laporan Nilai Tugas

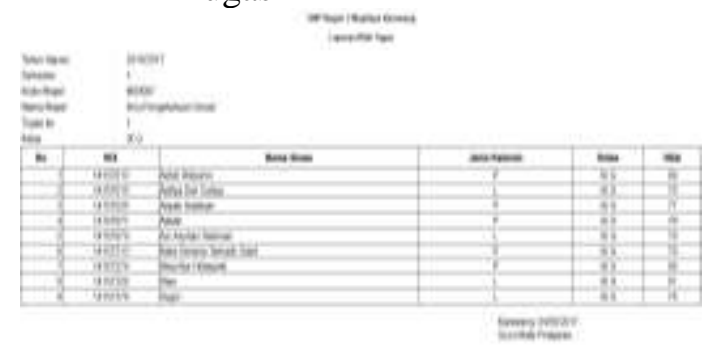

numu

Gambar 8. Tampilan Output Laporan Nilai Tugas.

b) Tampilan Output Laporan Nilai UTS

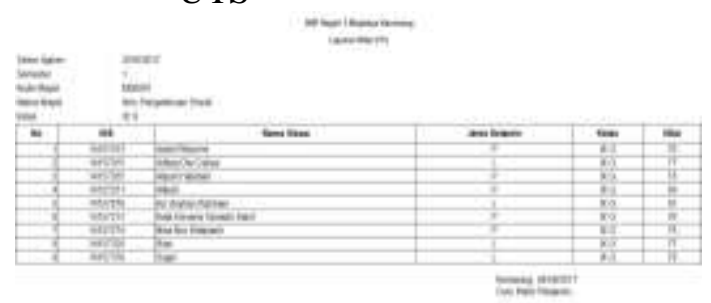

Gambar 9. Tampilan Output Laporan Nilai UTS. 
c) Tampilan Output Laporan Nilai Raport

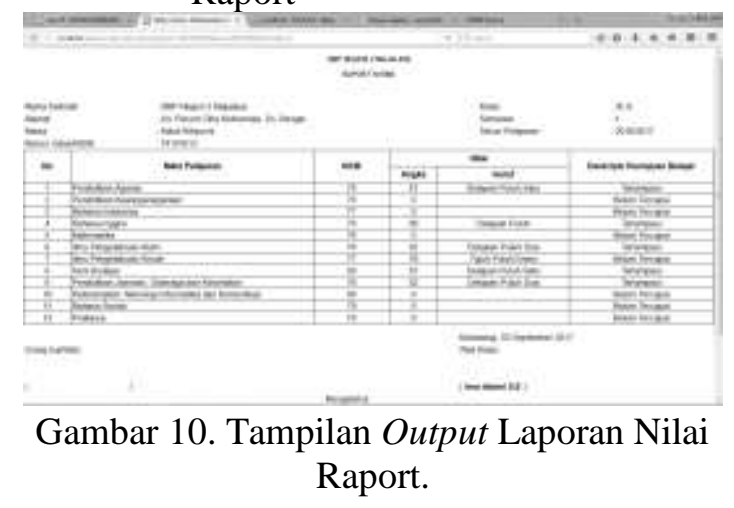

d) Tampilan Output Jadwal Mengajar Saya

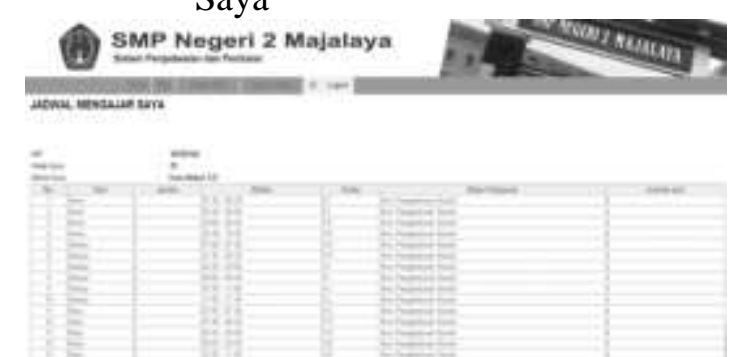

Gambar 11. Tampilan Output Jadwal Mengajar Saya.

\section{Kesimpulan Dan Saran}

\section{Kesimpulan}

Sistem Informasi Penjadwalan Mengajar dan Pengolahan Nilai Raport Pada SMP Negeri 2 Majalaya Karawang merupakan suatu perancangan untuk penjadwalan mengajar dan pengolahan nilai raport yang akan menghasilkan laporan nilai raport siswa dan penjadwalan mengajar yang tepat.

Berdasarkan uraian yang telah dibahas pada penelitian ini, Sistem Informasi Penjadwalan Mengajar dan Pengolahan Nilai Raport Siswa Pada SMP Negeri 2 Majalaya Karawang Berbasis Web akan banyak memberikan kemudahan dalam mengolah nilai, penjadwalan mengajar dan informasi, antara lain:

a) Dapat membantu menyajikan informasi penjadwalan mengajar dan pengolahan nilai yang akurat dan relevan. b) Dapat menghemat waktu untuk mencatat nilai dalam raport, nilai ledger, rekap nilai siswa seperti mencari data siswa dan data guru lebih mudah dalam menginformasikanya.

c) Meningkatkan kinerja dalam melakukan penyelesaian tugas dengan baik.

\section{Saran}

Adapun saran dari penulis untuk mempermudah informasi penjadwalan mengajar dan pengolahan nilai raport siswa adalah sebagai berikut :

a) Pemanfaatan media komputer sebagai tolak ukur arus informasi dan pendukung kemajuan teknologi sudah yang seharusnya diterapkan di Sekolah Menengah Pertama Negeri 2 Majalaya Karawang yang selama ini menggunakan cara kerja yang konvesional.

b) Program penjadwalan mengajar dan pengolahan nilai raport siswa yang telah dibuat oleh penulis khususnya dalam bahasa pemrograman $P H P$ dan databse PHPMyAdmin dapat menjadi informasi yang penting dan bermanfaat bagi SMP Negeri 2 Majalaya Karawang

c) Dengan adanya sistem ini dapat membantu dalam penjadwalan mengajar dan pengolahan nilai raport siswa di SMP Negeri 2 Majalaya Karawang.

\section{Daftar Pustaka}

Alawiyah Tuti dan Supriadi Deddy. 2015. Cara Cepat Membangun Website Dari Nol. Studi Kasus: Web Dealer Motor. Yogyakarta: CV Andi Offset.

Anhar. 2010. Panduan Menguasai PHP \& MySQL secara Otodidak. Jakarta : Media Kita.

Hutahaean Jeperson. 2014. Konsep Sistem Informasi. Yogyakarta: Deepublish.

Idi Abdullah. 2016. Pengembangan Kurikulum Teori \& Praktek. Jakarta : PT. Raja Grafindo Persada.

Kadir Abdul. 2014. Pengenalan Sistem Informasi. Yogyakarta : Deepublish.

M. Shalahuddin dan Rosa A.S. 2014. Rekayasa Perangkat Lunak. Informatika Bandung. 
Mahatmyo Atyanto. 2014. Sistem Informasi Akuntansi. Yogyakarta: Deepublish.

Muharto dan Arisandy. 2016. Metode Penelitian Sistem Informasi. Yogyakarta: Deepublish.

Putri, Nenzy Ahlung Arniyanto dan Anggit Dwi Hartanto. 2013. Sistem Informasi Pengolahan Nilai Raport Pada Siswa SMP Negeri 1 Yogyakarta Berbasis Web. ISSN : 1411-3201 No. 4 Vol. 14.6 halaman.

Sitorus Lamhot. 2015. Algoritma dan Pemrograman. Yogyakarta: CV. ANDI OFFSET

Subagia Anton. 2016. Membuat web dengan PHP 7 dan Database PDO MySQLi Jakarta: PT Elex Media Komputindo.

Sujarweni V Wiratna. 2014. Metodologi Penelitian. Jakarta: Pustaka Baru Press.

Susy Kusuma Wardani. 2013. Sistem informasi pengolahan data nilai siswa berbasis web pada sekolah menengah atas (SMA) muhammadiyah pacitan IJNS Volume 2 No 2 - April 2013 - ISSN: 2302-5700

Tyoso Jaluanto Sunu Punjul. 2016. Sistem Informasi Manajemen. Yogyakarta: Deepublish.

Wahyu Triyanto. 2013. Sistem Informasi Penjadwalan Mengajar dan Pengolahan Nilai Raport Secara Multiuser Pada SMK BHINEKA KARYA SIMO BOYOLALI. Jurnal TIKomSiN ISSN: 2338-4018 